\title{
Effect of Alkalic Salts on Hardening and Softening Properties of Soybean Protein-Water Suspending Systems
}

\author{
Jun-ichiro Umeya, Fumio Yamauchi and Kazuo ShIBasaki \\ Department of Food Chemistry, Faculty of Agriculture, \\ Tohoku University, Sendai 980 , Japan \\ Received July 28, 1980
}

\begin{abstract}
The effects of alkalic salts on the apparent viscosity of acid precipitated protein (APP) of soybean-suspending systems and heated gels were investigated using a modified coaxial cylinder viscometer. A hybrid program was established. (i) a cyclic temperature test $\left(20 \rightarrow 90 \rightarrow 20^{\circ} \mathrm{C}\right)$ under a constant shear rate and (ii) a cyclic shearing test $\left(48.7 \rightarrow 243.7 \rightarrow 48.7 \mathrm{sec}^{-1}\right)$ under isothermal conditions. The apparent viscosity of protein suspending systems $(12 \%$, wt/vol) gradually decreased with increasing temperature to about $70^{\circ} \mathrm{C}$. The apparent viscosity increased with a rise in temperature in the range of 70 to $90^{\circ} \mathrm{C}$, in ascending order of Hofmeister's series.
\end{abstract}

$$
\mathrm{SCN}^{-}>\mathrm{I}^{-}>\mathrm{Br}^{-}>\mathrm{Cl}^{-}>\mathrm{COOK}^{-}>\mathrm{F}^{-}>\mathrm{SO}_{4}^{2-}, \mathrm{Li}^{+}>\mathrm{Na}^{+}>\mathrm{K}^{+}
$$

With a fall in temperature, the apparent viscosity increased considerably in this order. The effect of anions to apparent viscosity was larger than that of cations at all measured temperatures in the gel-forming period.

The rheological properties of soybeangelation have been studied by many investigators. $^{1 \sim 3)}$ Some factors influencing rheological properties have been reviewed in soybean proteins. ${ }^{4}$ 6) A gelling phenomenon including a sol-progel-gel transition was reported by Catsimpoolas and Meyer. ${ }^{2)}$ The effect of alkalic salt on water-holding capacity and rheological properties of proteins have been studied by Aoki. ${ }^{7)}$

A previous study measured the gel forming properties at actual temperature in heating and cooling periods. Soybean protein-water suspending systems showed a considerable increase in viscosity at the end of the heating period compared to the cooling period. The studies of hardening and softening properties suggested that a concentration of $\mathrm{NaCl}$ effected the apparent viscosity. ${ }^{8}$. Hermansson reported that salts have a special effect on the behavior of soy protein, suppressing aggregation as well as denaturation. ${ }^{3)}$ The effect of $\mathrm{NaCl}$ on gel formation has been studied by Shimada and Matsushita. ${ }^{\text {9) }}$
It is possible, therefore, that salts in the system may influence the apparent viscosity of heated gel. In this study, the effect of various alkalic salts was measured in a cyclictemperatures test and a cyclic-shearing test by a modified coaxial cylinder viscometer. From these results, the relation of gel structure and viscosity is discussed.

\section{MATERIALS AND METHODS}

Defatted soybean meals. The soybean seeds (Glycine Max. var. Raiden, 1975 crop in Iwanuma, Miyagi, Japan) used in this work were stored at $5^{\circ} \mathrm{C}$, ground with a coffee mill, screened through a 60 -mesh sieve, and defatted with hexane.

Acid precipitated protein. The acid precipitated protein (APP) was prepared by extraction from the defatted meals with $0.03 \mathrm{M}$ Tris- $\mathrm{HCl}$ buffer $(\mathrm{pH} 7.8)$ and precipitated at $\mathrm{pH} 4.5$ and washed with the buffer. The protein was dialyzed against distilled water and lyophilized.

Buffers. Potassium phosphate buffer at 0.1 ionic strength contained $2.6 \mathrm{mM} \mathrm{KH}_{2} \mathrm{PO}_{4} 32.5 \mathrm{mM} \mathrm{K}_{2} \mathrm{HPO}_{4}$ and $4 \mathrm{~mm} \mathrm{NaN} \mathrm{N}_{3}$ (pH 7.8). Buffers with various alkalic salts 
were prepared by adding the salt $\left(0.4 \mathrm{M}\right.$ except for $\mathrm{K}_{2} \mathrm{SO}_{4}$, which is $0.2 \mathrm{M}$ ), to the potassium phosphate buffer. Salts of $\mathrm{K}_{2} \mathrm{SO}_{4}, \mathrm{KF}, \mathrm{CH}_{3} \mathrm{COOK}, \mathrm{KCl}, \mathrm{KBr}, \mathrm{KI}, \mathrm{KSCN}, \mathrm{NaCl}$, $\mathrm{LiCl}$ were added to the system. All the reagents were of the highest grade.

Suspending systems. Protein suspending systems (12\%, wt/vol) were prepared by mixing the protein with buffer under the isothermal conditions $\left(20^{\circ} \mathrm{C}\right)$.

Measuring apparatus. A coaxial cylindrical viscometer, Auto viscometer L type (Iwamoto Seisakusho Co., Ltd., Kyoto, Japan), modified partially by the addition of a temperature program controller, was programmed under a temperature range of $20^{\circ} \mathrm{C}$ to $90^{\circ} \mathrm{C}$ at a constant heating and cooling rate, and a shear range of 48.7 to $649.9 \mathrm{sec}^{-1}$. The viscosity at actual temperature is measured. The bob and the cup diameter were $3.0 \mathrm{~cm}$ and $2.8 \mathrm{~cm}$ respectively, and the immersion length was $7.9 \mathrm{~cm}$ and, therefore, the annular space was $0.1 \mathrm{~cm}$.

Measuring programs. Cyclic shearing programs were established $^{8)}$ for testing the thixotropic behavior of suspending systems and coagulated gels and monitoring apparent viscosity changes during heating and cooling period. All the suspending systems were exposed initially to violent disturbance $\dot{r}=649.9 \mathrm{sec}^{-1}(400 \mathrm{rpm})$ for $30 \mathrm{~min}$ and rested for $30 \mathrm{~min}$ in order to set the initial conditions. These measurements were made at $12 \%$ (wt $/ \mathrm{mol}$ ) concentration of proteins. This series of tests was ascertained by check-run, and the data obtained was processed by a computer.

\section{RESULTS}

Flow curves for protein-suspending system: effect of anions

All flow curves reported here were measured at $20^{\circ} \mathrm{C}$. The effect of shear rate on the apparent viscosity for protein-suspending systems is shown in Fig. 1. In the shear rate range of 48.7 to $243.7 \mathrm{sec}^{-1}$, the apparent viscosity of all suspending systems decreased with an increase in the shear rate. This decreasing tendency was noticeable at lower shear rates. Considerable hysteresis loops were obtained in all flow curves. However, the system with $\mathrm{K}_{2} \mathrm{SO}_{4}$ showed a lower apparent viscosity and a larger hysteresis loop. All suspending systems showed a time-dependent flow property and behaved as thixotropic.

\section{Heated gel-forming property; effect of anions}

The relationship between the apparent vis-

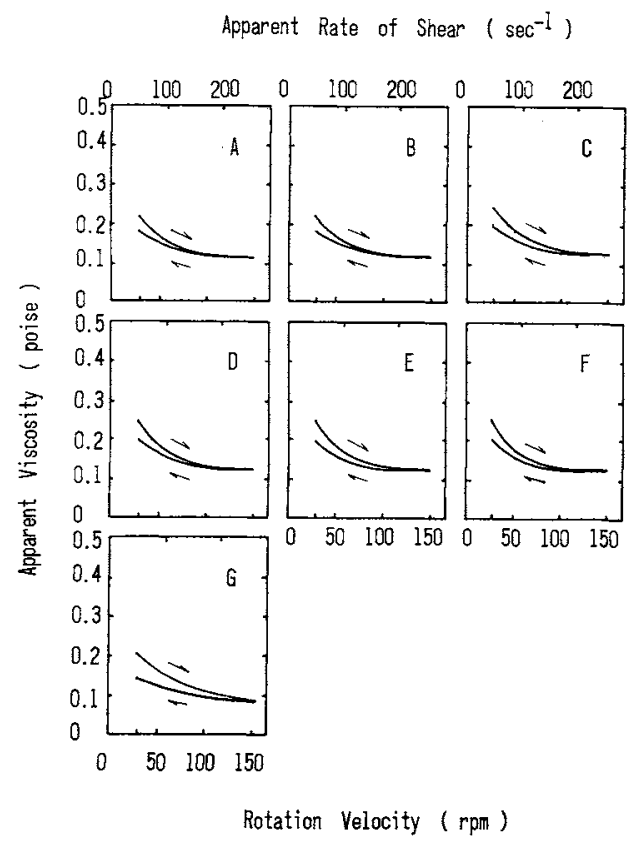

FIG. 1. Effect of Anion on Hysteresis Relations between Apparent Viscosity and Rate of Shear of ProteinWater Suspending Systems $(12 \%$, wt $/ \mathrm{vol})$ at $20^{\circ} \mathrm{C}$.

0.4 м KSCN (A), $0.4 \mathrm{M} \mathrm{KI}$ (B), $0.4 \mathrm{M} \mathrm{KBr}$ (C), $0.4 \mathrm{M} \mathrm{KCl}$ (D), $0.4 \mathrm{M} \mathrm{CH}_{3} \mathrm{COOK}$ (E), $0.4 \mathrm{M} \mathrm{KF}$ (F), 0.2 M K $\mathrm{SO}_{4}$ (G).

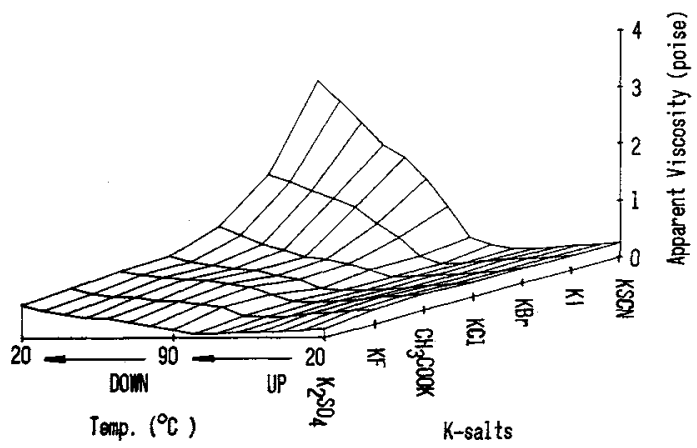

FIG. 2. Temperature Effect on Apparent Viscosity of Protein-water Suspending Systems (12\%, wt/vol) under the Shear Rate of $81.2 \mathrm{sec}^{-1}$ during Constant Rate $\left( \pm 70^{\circ} \mathrm{C} / 1 \mathrm{hr}\right)$ of Heating and Cooling Period.

Concentration of salts were $0.4 \mathrm{M}$ except $\mathrm{K}_{2} \mathrm{SO}_{4}$ which is $0.2 \mathrm{M}$.

cosity and both heating and cooling temperature was measured and demonstrated by threedimentional graphs $^{10)}$ in Fig. 2. These tests were conducted under conditions where constant mechanical disturbance $\left(\dot{r}=81.2 \cdot \mathrm{sec}^{-1}\right)$ 
was governed.

Generally, the protein-suspending system indicates an apparent viscosity curve gently decreasing with an increase in temperature in the range of about $20^{\circ}$ to $70^{\circ} \mathrm{C}$ in the heating period, and an increase in apparent viscosity with an increase in temperature at the final stage of the heating period from about $70^{\circ}$ to $90^{\circ} \mathrm{C}$. The apparent viscosity of the system increased considerably in the initial stage of the cooling period of about $90^{\circ}$ to $60^{\circ} \mathrm{C}$ and increased more, considerably in the period from $60^{\circ}$ to $20^{\circ} \mathrm{C}$. This tendency occurred in all samples.

In the range from $20^{\circ}$ to $70^{\circ} \mathrm{C}$ in the heating period, a slight difference was shown in the systems with some salt. In the range of $70^{\circ}$ to $90^{\circ} \mathrm{C}$ in the heating period, the apparent viscosity of the systems with those of alkali ions increased in the following order, $\mathrm{SO}_{4}{ }^{2-}<$ $\mathrm{F}^{-}<\mathrm{COOK}^{-}<\mathrm{Cl}^{-}<\mathrm{Br}^{-}<\mathrm{I}^{-}<\mathrm{SCN}^{-}$. In the cooling period, the apparent viscosity of the system increased considerably in that order, with those of alkali ions.

\section{Flow curves for heated gels; effect of anions}

The effect of the shear rate on the apparent viscosity at $20^{\circ} \mathrm{C}$ for a heated gel is shown in Fig. 3. After cyclic temperature testing the resulting samples were used for heated gels. Before measurement, samples were rested for 30 min to set the initial conditions. In the shear rate range of 48.7 to $243.7 \mathrm{sec}^{-1}$, the apparent viscosity of all gels decreased as the shear rate increased, this decreasing tendency was quite noticeable at a lower shear rate. Larger hysteresis loops were observed in all heated samples. It can be seen that hysteresis looping increased as the system indicated higher apparent viscosity.

Flow curves for protein-suspending system; effect of cations

There was a small variation among three flow curves (Fig. 4). Apparent viscosity decreased with an increase in the shear rate. This decreasing tendency was noticeable at lower shear rates. All suspending systems showed a

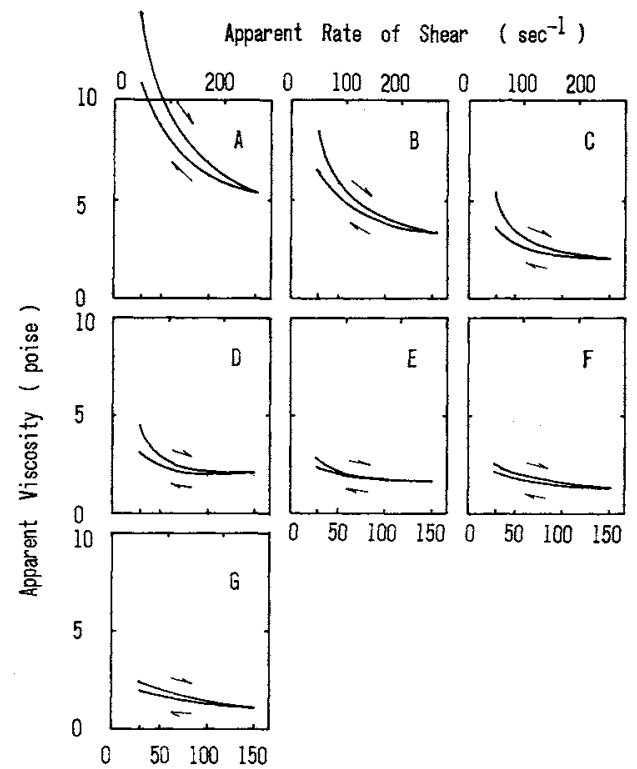

FIG. 3. Effect of Anion on Hysteresis Relations between Apparent Viscosity and Rate of Shear of Heated Gels $(12 \%, w t / v o l)$ at $20^{\circ} \mathrm{C}$.

$0.4 \mathrm{M} \mathrm{KSCN}(\mathrm{A}), 0.4 \mathrm{M} \mathrm{KI}(\mathrm{B}), 0.4 \mathrm{M} \mathrm{KBr}(\mathrm{C}), 0.4 \mathrm{M} \mathrm{KCl}$ (D), $0.4 \mathrm{M} \mathrm{CH}_{3} \mathrm{COOK}(\mathrm{E}), 0.4 \mathrm{M} \mathrm{KF}(\mathrm{F}), 0.2 \mathrm{M} \mathrm{K}_{2} \mathrm{SO}_{4}$ (G).

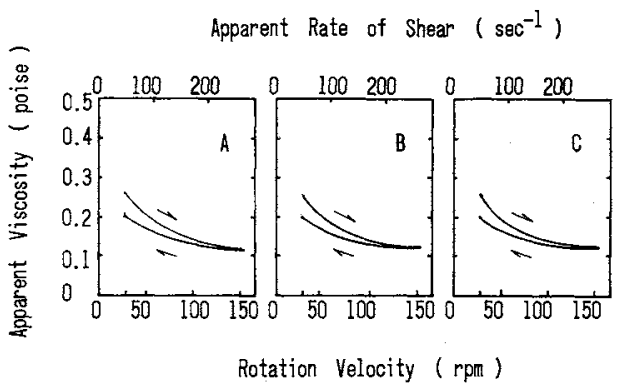

FIG. 4. Effect of Cation on Hysteresis Relations between Apparent Viscosity and Rate of Shear of Protein-Water Suspending System $(12 \%$, wt $/$ vol) at $20^{\circ} \mathrm{C}$.

$0.4 \mathrm{M} \mathrm{LiCl}$ (A), $0.4 \mathrm{M} \mathrm{NaCl}$ (B), $0.4 \mathrm{M} \mathrm{KCl} \mathrm{(C).}$

time-dependent flow property and behaved as thixotropic.

Heated gel-forming property; effect of cations

These tests were conducted under the same conditions as those of anions. The apparent viscosity of all samples decreased with a rise in temperature in the range of $20^{\circ}$ to $70^{\circ} \mathrm{C}$ in the 
heating period, and increased apparent viscosity at the final stage of the heating period from about $70^{\circ}$ to $90^{\circ} \mathrm{C}$. (Fig. 5) The apparent viscosity of the system increased considerably in the cooling period.

In the range from $70^{\circ}$ to $90^{\circ} \mathrm{C}$ in the heating period, the apparent viscosity of the systems with these of cations increased in following order, $\mathrm{Li}^{+}>\mathrm{Na}^{+}>\mathrm{K}^{+}$. In the cooling period, the apparent viscosity of the system increased in that order, with those of cations. However, this tendency was smaller than that of anions.

\section{Flow curves for heated gels; effect of cations}

The effect of the shear rate on apparent viscosity for heated gels, which was obtained under the same conditions as that of anion, is shown in Fig. 6. Larger hysteresis loops and higher apparent viscosity were observed than those of the suspending systems.

\section{DISCUSSION}

In this study, soybean protein was measured at an ionic strength of 0.5 except for $\mathrm{K}_{2} \mathrm{SO}_{4}$. Soybean globulins have been dissolved at this ionic strength by most investigators. $\mathrm{Ca}^{2+}$ and $\mathrm{Mg}^{2+}$ were omitted in this study, because these cations showed the maximum gelation at far lower ionic strength.

Suspending systems of soy proteins indicated a flow pattern having a timedependent character, namely thixotropy. Only small variations were observed among anions and among cations, except for $\mathrm{K}_{2} \mathrm{SO}_{4}$. The system with $\mathrm{K}_{2} \mathrm{SO}_{4}$ showed lower apparent viscosity and larger hysteresis looping. (Fig. 1) Others showed almost the same value of apparent viscosity and area of hysteresis looping as those of $\mathrm{NaCl}$, obtained under the same conditions.

As was shown in Fig. 2 the apparent viscosity decreased with a rise in temperature from $20^{\circ}$ to $70^{\circ} \mathrm{C}$, which is typical for a suspending system without side reaction. In this period no gel formation occurred and the three-dimensional crosslinked network had not formed in the system. The apparent

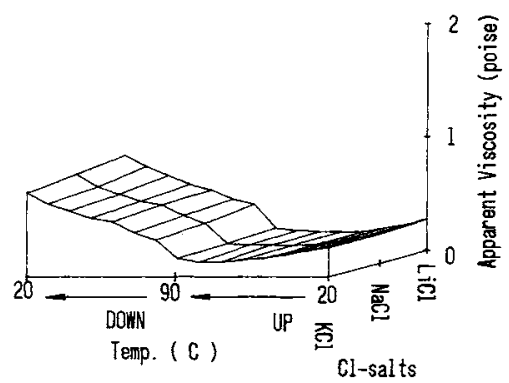

Fig. 5. Temperature Effect on Apparent Viscosity of Protein-Water Suspending Systems (12\%, wt/vol) under the Shear Rate of $81.2 \mathrm{sec}^{-1}$ during Constant Rate $\left( \pm 70^{\circ} \mathrm{C} / 1 \mathrm{hr}\right.$ ) of Heating and Cooling Period.

Concentration of salts was $0.4 \mathrm{M}$.

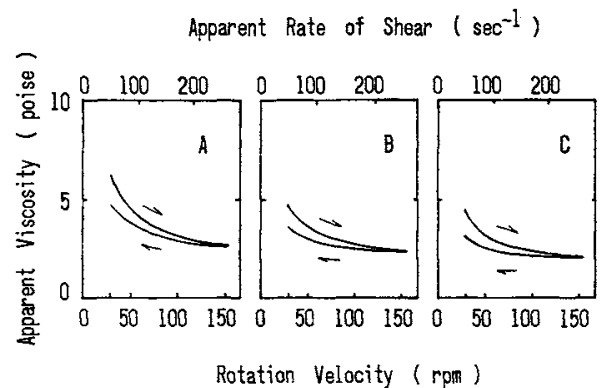

FIG. 6. Effect of Cation on Hysteresis Relations between Apparent Viscosity and Rate of Shear of Heated Gels $(12 \%$, wt $/ \mathrm{vol})$ at $20^{\circ} \mathrm{C}$.

$0.4 \mathrm{M} \mathrm{LiCl}$ (A), $0.4 \mathrm{M} \mathrm{NaCl}$ (B), $0.4 \mathrm{M} \mathrm{KCl}$ (C).

viscosity of each system is almost at the same value at any temperature in this period. After $70^{\circ} \mathrm{C}$ the apparent viscosity rose with the rise in temperature. This suggests that gel formations is initiated in this period. The order of apparent viscosity is the same as Hofmeister's serres, ${ }^{11)}$ as given below.

$$
\begin{aligned}
\mathrm{SCN}^{-} & >\mathrm{I}^{-}>\mathrm{Br}^{-}>\mathrm{Cl}^{-}>\mathrm{COOK}^{-}> \\
\mathrm{F}^{-} & >\mathrm{SO}_{4}^{2-}, \mathrm{Li}^{+}>\mathrm{Na}^{+}>\mathrm{K}^{+}
\end{aligned}
$$

The effect of anion to proteins is related to Hofmeister's series and to water holding capacity. ${ }^{6)}$ Hydrophobic interaction is favorable from $70^{\circ}$ to $90^{\circ} \mathrm{C}$. This viscosityincreasing tendency suggests that the protein unfolds under the heat treatment and the unfolding part exposes active groups of the protein. Consequently, the three-dimensional 
intermolecular networks begin to build up in this region.

With a fall in temperature apparent viscosity increases considerably, accompanied by the rigid-structure formation which produces a tightly cross-linked gel structure. Also it seems likely that ionic and hydrogen bonds were formed after hydrophobic interactions. The order of apparent viscosity is the same as Hofmeister's series throughout the cooling period. The effect of anions to apparent viscosity was larger than that of cations at any temperature in the gel forming period.

The flow curves for heat induced gel are shown in Fig. 4. All the systems showed timedependent flow character, behaved thixotropic, and increased the hysteresis-loop area and apparent viscosity considerably. This indicates the existence of a rigid quasi structure. The order of apparent viscosity is the same as Hofmeister's series and also the same as that before heat treatment. The portion of the hysteresis-loop area is almost the same value.

Salts affect ionic and hydrogen bonds and enhance hydrophobic interaction. However, the effect of salts on protein-protein interaction in a gel was highly complicated. The addition of salts resulted in a higher gel viscosity in the ascending order of Hofmeister's series. It seems that the effects of the salts is related to a degree of denaturation of the globulin. The unfolding of the globulin was accompanied by the exposure of nonpolar groups and resulted in the higher gel forming capacity.

In this investigation a moderate mechanical disturbance $\left(81.2 \mathrm{sec}^{-1}\right)$ existed in the cooling and heating period. This will constantly disturb a formation of some weaker interactions of gel structure. However, the viscosity may indicate a magnitude of quasi structure of gels.

\section{REFERENCES}

1) S. J. Circle, E. W. Meyer and R. W. Whitney, Cereal Chem., 41, 157 (1964).

2) N. Catsimpoolas and E. W. Meyer, Cereal Chem., 47, $599(1970)$.

3) A. M. Hermansson, J. Texture Studies, 9, 33 (1978).

4) K. Saio and T. Watanabe, J. Texture Studies, 9, 135 (1978).

5) J. E. Kinsella, J. Am. Oil Chemists' Soc., 56, 242 (1979).

6) F. Yamauchi, Nippon Shokuhin Kogyo Gakkaishi, 26, 6 (1979).

7) H. Aoki, Nippon Nôgeikagaku Kaishi, 39, 277 (1965).

8) J. Umeya, F. Yamauchi and K. Shibasaki, Agric. Biol. Chem., 44, 1321 (1980).

9) K. Shimada and S. Matsushita, Agric. Biol. Chem., 44, 637 (1980).

10) W. M. Newman and R. F. Sproull, "Principles of Interactive Computer Graphics," McGraw-Hill, Maidenhead, England, 1973.

11) D. R. Robbinson and W. P. Jencks, J. Am. Chem. Soc., 56, 2470 (1965). 